\title{
GLACIER MAPPING FOR AN INVENTORY OF THE INDUS DRAINAGE BASIN: CURRENT STATE AND FUTURE POSSIBILITIES
}

\author{
by
}

W. Kick

(Macheinerweg 35, D-84 Regensburg, West Germany)

\begin{abstract}
A large problem of the World Glacier Inventory is the Pakistan part which is still missing. The available official quarter-inch and half-inch maps of the Survey of India and Pakistan are not adequate for the purpose. The maps of some expeditions provide reliable data for a few areas. Landsat imagery does not yield heights and has other disadvantages. At the present time, the Spacelab mission, in September 1986, with its metric camera, seems to offer a rather good opportunity.
\end{abstract}

\section{INTRODUCTION}

The river system of the Indus gets its water from thousands of glaciers and is of vital importance to millions of people. Therefore the glacier inventory of the catchment area of this river system is extremely important. The Indus system covers an area that includes not only almost the whole of Pakistan, but also parts of India, China, and Afghanistan. But, as stated in a recent report on the World Glacier Inventory (Scherler 1980, p.17), "the missing Pakistan inventory remains one of the large problems to be solved". In the following, the usefulness of 1) official maps, 2) expedition maps, 3) satellite imagery, for the completion of the inventory and, finally, 4) the opportunity which satellite photogrammetry will provide, in future, are outlined.

\section{OFFICIAL MAPS}

The whole area of India and Pakistan is covered by quarter-inch (1:253440) and partially by half-inch (1:126 420) maps of the Survey of India (S.o.I.) and now also of Pakistan. Experiences with the sheets No. 43M, $52 \mathrm{~A}$, and 43I may show the level of adequacy. Only these examples are given, because the mapping work of the author, at the Chogo Lungma (CL) Glacier and at some Nanga Parbat (NP) glaciers was, by chance, concerned with them.

First example: Part of sheet $43 \mathrm{M}$

The representation of the glacier systems of $\mathrm{CL}$ and Baltoro, on the official map-sheets $43 \mathrm{M}$ and $52 \mathrm{~A}$, is based on the plane-table work of Godwin-Austen, an officer of the S.o.I., which he carried out in 1860-61 (1:513 510) (Godwin-Austen 1864). His work was based on the intersected points (peaks) of Montgomerie's Kashmir Principal Triangulation of 1855-60. Although Godwin-Austen had only two days at his disposal for mapping work at the glacier region of $\mathrm{CL}$, his map showed this huge glacier area fairly well.

In the Triangulation Pamphlets, which have been edited by the S.o.I. for each map-sheet, it was announced: "Travellers intending to visit or explore any of the lesser-known portions of the area (of the relevant sheet) are invited to communicate with the Superintendent of the Trigonometrical Survey, Dehra Dun, who will be glad to receive corrections or additions of interest....." Contributions by surveyors connected with expeditions were welcomed.

In 1902 and 1903, the well-known American Karakoram explorers, Fanny Bullock and William Hunter Workman, visited the CL region. They employed a British surveyor, B.H.M. Hewett, who compiled a map of the whole area on a scale greater than that of the official map, namely at 1:150000 (Workman and Workman 1908). But, in common with the expedition leaders, Hewett believed that the "Pyramid Pk" was the highest in the $\mathrm{CL}$ region, instead of Malubiting. They all committed an error in the height of this peak $(\mathrm{Pk} 68 / 42 \mathrm{~L}=$ Ghenish Chish $=$ Yengutz Har $=$ Spantik is $7027 \mathrm{~m}$ ) by more than $500 \mathrm{~m}$, since they thought it to be at least $100 \mathrm{~m}$ higher than Malubiting (Pk $46 / 42 \mathrm{~L}=$ Indus-Nagar-Watershed, $(-\mathrm{Pk}$ No 2 is $7458 \mathrm{~m})$. They measured height by barometer, not by theodolite. This error had consequences also in the mapping of the surrounding area. The shape of the $45.1 \mathrm{~km}$-long CL glacier stream had formerly been correctly represented in the map of Godwin-Austen and thus in the Survey map. It had shown an almost rectangular bend, $7 \mathrm{~km}$ distant from the glacier terminus. In the Workman-Hewett map, however this existing and striking feature had disappeared. The officers of the S.o.I. transferred this wrong representation to the official map, as a "correction", i.e. they made the official map worse than it was before. Almost all portions of the official sheet, $43 \mathrm{M}$, contain only "form lines" instead of contour lines. They give no correct representation of the topography. Altitudes a.s.l., given on the quarter-inch maps by spot height figures, can be wrong by $160 \mathrm{~m}$, e.g. the old village, Arundu, just in front of the terminus of the CL glacier, is marked as 9594 , instead of $9088 \mathrm{ft}$. The peak Shuntun, $9 \mathrm{~km}$ north-east from Arandu, is marked as 18160 , instead of $17623 \mathrm{ft}$ (see below). The peak "Riffelhorn", at the north-west corner of sheet $43 \mathrm{M}$, is marked as 15337 (as established by Workman), instead of $14738 \mathrm{ft}$ and the "Pyramid" is given on Workman's map at 24500 , instead of its actual height of $23056 \mathrm{ft}$.

\section{Second example: Uncertainty of altitudes a.s.l.}

Five of the 14 highest mountains of the earth (the "8000 m peaks") feed the glaciers at the head of the Indus basin from their snowy or icy slopes or walls. The coordinates of all these peaks were determined during the Kashmir Triangulation of $1855-60$ as "intersected points". They have not yet been re-triangulated with the same accuracy as, e.g., Mt. Everest. Publications in popular journals, such as the Bergsteiger, claim that the Survey of Pakistan has given a new height to $\mathrm{K} 2$, the second highest mountain after Mt. Everest, namely $8760 \mathrm{~m}$, against $8611 \mathrm{~m}$, the figure which has been valid now for 130 years. If that is true - and it has been published that the S.o.Pak. has confirmed it to the American Alpine Club then several other intersected points may also change their heights and the whole topography of the area would become higher by about $150 \mathrm{~m}$. This would affect all height figures important for glaciological studies.

Another example of the unreliability of even official heights of the same area is Broad Peak (Pk 16/52A until 1926 , then $\mathrm{Pk} 62 / 52 \mathrm{~A})$. It is another $8000 \mathrm{~m}$ peak at the margin of the catchment area of Baltoro Glacier. It had been marked on the official map at $8270 \mathrm{~m}$, also since the triangulation of 1855-60. But, in 1926, Kenneth Mason of the S.o.I. reduced this figure by $233 \mathrm{~m}$. 


\section{Third example: Part of sheet $43 \mathrm{I}$}

This sheet is much more accurate than $43 \mathrm{M}$, because it is compiled by official surveys only. But, even in this map, it is noted that the $(250 \mathrm{ft})$ contours are only approximate. The applicability for the purposes of the WGI may be estimated by the following: Out of the 69 WGI glaciers of the NP massif (Kick 1980), only 13 are shown on the official map 43I. It is not possible to determine on it such parameters as areas or lengths, because only the tongues of these 13 are shown, not the accumulation areas. The elevations (only of the termini) can be determined with a precision of about $\pm 80 \mathrm{~m}$ or worse, not accurate enough for the inventory.

\section{Fourth example: The Afghan part of the Indus basin}

For this part, I refer to the excellent article of Schroder (1980). Though there are official maps on a scale of 1:100000, "access to maps has been the major problem.... Contours, elevations, latitude and longitude appear to be incorrect in several cases .... regions close to the borders are largely unmapped ... depicted ice-cored moraines are interpretive only and apparently make the glaciers much larger than they really are ... classification of glacier type and basin is very difficult with $1: 100000$-scale maps ... the 1:50 000-scale maps were nearly completely unavailable ..."

For two of the four Afghan branches, the inventories were already completed in 1978. They comprise 440 glaciers.

\section{Result}

The portions of the sheets $43 \mathrm{M}, 52 \mathrm{~A}$, and $43 \mathrm{I}$, of the official map series, which could be checked, do not yield information suitable for the needs of the WGI. It is more than probable that the same is true for the other quarterand half-inch maps. It is most likely that now there are better maps from aerial surveys, but these may not be for public use.

\section{EXPEDITION AND OTHER MAPS}

Only those cases are treated which are important for the WGI.

\section{a) Shipton-Mott's map}

"Hispar-Biafo-Glacial Regions" - Karakoram Expedition

1939. Scale 1:253 440 (S-M's map).

The largest and probably the most important glacier area of the Indus basin which was ever mapped by private expedition, is that from the Huuza valley over Hispar-Biafo and Panmah glaciers to the New Mustag Pass. This work was done in 1939 by Peter Mott and the two plane-tablers, Fazal Ellahi and Inayat Khan, of the S.o.I.

Only the height of one peak could be checked. It is situated in a small part of the mapped area, which was surveyed towards the end of the expedition by a "rapid plane-table survey by P. Mott" (Mott 1950). This is the peak, Shuntun, already mentioned above.

It is marked too high by $164 \mathrm{~m}$. This wrong height was transferred from S-M's map to the official sheet $43 \mathrm{M}$. Other portions of the map are assumed to be more accurate, although only a part of the Hispar Glacier was triangulated, using a Wild T2 theodolite. Other parts had to be based on a triangulation with a TAL phototheodolite. reading only to 1.5 minutes. Some areas were mapped by the plane-tablers, others by the "single picture method of photographic mapping", which already Sebastian Finsterwalder had introduced to glacier mapping in the Ötztal Alps in the years 1888-89. The photographs of 1939 were evaluated graphically; those of $1888-89$ by computing 833 points, using 2329 intersecting forward shots, taken from the pictures. In 1888-89 analytical, single-picture photogrammetry was used; after 1939 analogous photogrammetry was performed.

S-M's map covers as much as $3500 \mathrm{~km}^{2}$. It seems to provide most of the inventory parameters if one does not expect a high level of accuracy.

b) Minapin 1:50000; expedition of 1954 and 1959 (Schneider 1968).

Seven of the numerous glaciers of S-M's survey were mapped for a second time, on a much bigger scale, by the German-Austrian Hunza expeditions. These are the Minapin, together with six other glaciers in the area around it. The method was terrestrial stereo-photogrammetry, based on a triangulation. The contours are drawn continuously by stereoscopic evaluation on a plotting machine. The result is, of course, of an essentially higher level of accuracy and therefore S-M's small-scale map can be checked by it. Some proofs show that the heights of the glacier termini can be determined by S-M's map with an accuracy of 100 to $200 \mathrm{~m}$. Lengths and breadths of glacier tongues can be measured within an error of 10 to $20 \%$.

Besides Workman's CL and S-M's maps, data from several other expedition maps have been transferred to the official quarter-inch maps, e.g:

c) Martin Conway's survey of 1892 of Hispar and Biafo, or

d) Longstaff's mapping work of 1909, in the Eastern Karakoram, or

e) Negrotto's map of a portion of the Baltoro (1909), using what Mott called "the single-picture method of photographic mapping" (in German "Meßtischphotogrammetrie"), or

f) Workman's Siachen map of 1912 (plane-table, 1:150 000; published in the Geographical Journal, 1914). Mason, Shipton and Dyhrenfurth found this map not reliable enough for scientific work, though Grant Peterkin had observed a trigonometrical net over the whole Siachen basin and Sarjan Singh's plane-table survey was transformed to the sheets $52 \mathrm{~A}$ and $52 \mathrm{E}$.

g) In 1926-27 Kenneth Mason surveyed regions of the upper Shyok for the Half- and quarter-inch official maps. h) In 1929, the Italians M.Cugia and A.Desio, did stereophotogrammetric work at the Baltoro, Panmah and other glaciers. Three large sheets on a scale of $1: 75000$ were the result. The Panmah part was again mapped by Shipton's expedition in 1939. P. Mott made no mention of the Italian forerunner, in his account of the genesis of S-M's map. Obviously, nothing of the 1929 map had been considered. But, in 1954, the Italian K2 expedition (Ardito Desio; Marussi etc.) added some stereo-photogrammetric surveys of small parts of the Baltoro. After this, a Baltoro map, on a scale of 1:100000, with $100 \mathrm{~m}$ contour lines was published by the Istituto Geografico Militare, in 1969 (2nd edition 1977). This map is assumed to meet the WGI requirements

i) In the years 1925 to 1935 , Ph.C. Visser had Afraz Gul survey some regions on the half-inch scale. Some of this plane-table work was also transcribed on to the official sheet, $52 \mathrm{E}$ in this case. Most of it refers to areas north of the Indus system.

j) In 1937, the Shaksgam Expedition of Shipton and Spender mapped several areas, most of them outside the Indus system, but also the upper branches of the Panmah Glacier $(1: 250000)$ (Spender 1938). This map too is not mentioned by Mott (1950).

k) A very reliable expedition map is that of the Nanga Parbat massif. It contains $224 \mathrm{~km}^{2}$ of glacierized area out of the $1600 \mathrm{~km}^{2}$ of the whole map-sheet. The field work was done by Richard Finsterwalder, in 1934. The scale is 1:50 000; the contour interval $50 \mathrm{~m}$. The geodetic basis is a triangulation, with a special adjustment to determine the relative deviations from the vertical. I have already used this map, together with the original photographs, for the WGI (Kick 1980). All of the data are card-punched and are available in computer print-out from TTS/WGI, VAW/ETH Zürich. In 1958, the tongues of the six most important glaciers on the south and east sides were resurveyed, again by stereo-photogrammetry. The variations from 1934 to 1958 proved to be much smaller than those of the glaciers of the Alps, not only of the termini, but also of the amounts of surface shrinking. Therefore, the old data of 1934 for the other glaciers of the NP inventory are not as bad as they seem at first sight.

1) The Chogo-Lungma map of 1954 (1:100000), with special sheets on scales of 1:25000 and 1:12 500, is appropriate for an inventory of the main glacier stream, but only for the lower parts of the 17 side glaciers (Kick 1964). The terminus area of the main stream had already been resurveyed in 1970 and 1979 (Best et.al. 1982).

m) In 1978 the Lanzhou Institute of Glaciology and Geocryology published a map of the Batura glacier system 
(1:60 000; $20 \mathrm{~m}$ contours), which provides all information needed for the WGI. Probably the Chinese glaciologists did not know of a survey of the same glacier, also performed by terrestrial stereo-photogrammetry, by the GermanAustrian Hunza expeditions of 1954 and 1959. This work was never finished and so did not lead to a complete map. But a proof, with $50 \mathrm{~m}$ contours, plotted on a stereoautograph, has been produced. This incomplete map not only contains the Batura, but also several glaciers of the Hunza-Karakoram, south of it.

Unfortunately, the Lanzhou map does not contain a grid net, nor an orientation towards the North. But one can compare positions and heights, after reduction of the unpublished map from 1:50000 to 1:60 000. Height figures, especially peaks, differ by 5 to $15 \mathrm{~m}$ between the two maps. The contours at the glacier surface, in connection with those outside, make it possible to determine the volume changes for the period from 1954 to 1974. The height differences there may be assumed to have an accuracy of 3 to $5 \mathrm{~m}$, whereas the the amounts of shrinkage at some distance from the terminus are much greater.

At any rate, by virtue of the Chinese map, the Batura glacier system has become one of the parts of the Indus basin for which the WGI could be, and has already been, accomplished (Shi and Zhang 1984).

\section{$\underline{\text { Result }}$}

For some relatively small, though rather considerable, fractions of the whole Indus drainage basin, some expedition maps provide information for the WGI. They may be used for checking other sources, e.g. satellite imagery.

\section{SATELLITE IMAGES}

Since Landsat imagery consists only of single pictures, it does not yield information on heights. If it can be used at all for the WGI, then it is only in correlation with topographic maps. The standard deviation of measured lengths, such as amounts of glacier advance or retreat, has been found to be $\pm 10 \%$ (Mi and Luo 1983). But this accuracy may only be achieved in favourable cases. Because of the debris cover of the majority of the Asiatic glaciers, one cannot identify the precise glacier termini. In the accumulation areas, the same difficulties of interpretation appear.

An advantage of Landsat is the repetitive coverage of the same areas 20 times per year. Therefore there is an opportunity to get pictures without cloud cover, free of fresh snow cover, and at a time near to the end of the ablation season.

Better results can be obtained by the computercompatible tapes for Landsat scenes. This digital information has been utilized rather successfully for glacier information, "that is, for some purposes, as good as that to be gained from maps of scale 1:250 000" (Rundquist 1980).

Combined with other sources, series of space images, obtained by the orbital station "Saljut-6", have been used for compiling glaciological maps of the Karakorum in the World Atlas of Snow and Ice Resources (Desinov et.al. 1981). By this method, the whole of the Indus basin is depicted on these maps. But, as mapping from space images generally has "not reached the level of national cartographic surveying" (Kravtsova 1981-82), it is assumed that this work can meet the demands of the WGI only in connection with topographic maps.

\section{THE MOST PROMISING PROGRESS IS THAT OF SATELLITE STEREO-PHOTOGRAMMETRY}

In December 1983, Spacelab, in its first mission, carried a metric camera, by means of which photographs of High Asia (China, Nepal, Mt. Everest region) were taken (Konecny 1984). Since the photography had an $80 \%$ overlap, pairs of pictures can be used to plot conventional photogrammetric line maps, as well as orthophoto maps on the scale of 1:100 000. Height can be determined and contours can be drawn. In 1983, the territory of the Indus basin had not been photographed. Since, during this first Spacelab mission, there had been several unfavourable circumstances (e.g. rather limited time for this metric camera experiment as one of 37 experiments, cloud cover, insufficient elevation of the sun), another flight will take place on September 3, 1986. Once again, a NASA space shuttle will carry Spacelab for about a week. The metric camera mounted on the Spacelab will be improved by a movement compensator. Thus the exposure time can be longer, so the resolution will be higher. It is hoped that maps of 1:50000 scale can then be plotted, with a height accuracy of $10 \mathrm{~m}$.

Whether the metric camera of Spacelab missions will solve the problem of the glacier inventory of the Indus drainage basin depends on financial possibilities and also the weather conditions. But this time there is hope

\section{EXISTING GLACIER INVENTORIES OF THE INDUS DRAINAGE BASIN}

There exists an unpublished inventory, compiled by the Engineering Office of A.V. Karpov, New York City, 1967 It contains 1386 glaciers, a quarter of the total. But, for most of them, only four of the forty required parameters of the WGI are given. The data come from the AMS maps on the 1:250000 scale. Out of the 69 glaciers of the NP massif, Karpov listed, for instance, only 15 . The parameters are erroneous in many cases, e.g. the direction of Mazeno Glacier is maintained to be east, instead of south-west and south. The length of Chungpar is given as 4.5 miles, instead of 6.4 miles (mean length) and 7.5 miles (max. length). For many glaciers, Karpov gives no heights at all, e.g. none for the glaciers of the NP. Karpov's inventory is in no way adequate for the requirements of the WGI. It was ordered by the WAPDA, Lahore (Water and Power Development Authority). Later on, this organization itself established a "preliminary inventory", using Landsat imagery of 1977, together with existing maps. But it is not only very incomplete - e.g. the glaciers of the Chitral basin, or the great Batura are absent - but several glaciers are arranged at wrong basins. CL is listed with a length of $61.82 \mathrm{~km}$ instead of $45 \mathrm{~km}$; its area is given as 119.31 instead of $320 \mathrm{~km}^{2}$. The elevation of the terminus is given as 2897 , instead of $2750 \mathrm{~m}$, etc.

So far as I know the WGI of the Indus drainage basin has been established only for Afghanistan (Schroder 1980), the Batura glacier area (Shi and Zhang 1984), and the Nanga Parbat massif (Kick 1980). The greater part of the work has still to be done.

\section{REFERENCES}

Best F, Gruber G, Kick W 1981 Das Ende des Chogo-Lungma-Gletschers 1979. Zeitschrift für Gletscherkunde und Glazialgeologie 17(2): 177-189

Desinov L V, Ivanchenkov A S, Kotlyakov V M, Nosenko G A 1982 Rezul'taty eksperimenta po izucheniyu oledeniya Karakoruma s borta orbital'noy stantsi "Salyut-6" [Results of experimental studies of Karakorum glaciers from aboard "Salyut-6" orbital station]. Materialy Glyatsiologicheskikh Issledovaniy. Khronika. Obsuzhdeniya 42: $22-40$

Godwin-Austen H H 1864 On the glaciers of the Mustakh Range. [With map.] Journai of the Royal Geographical Society 34: 19-56

Kick W 1964 Der Chogo-Lungma Gletscher im Karakorum. Zeitschrift für Gletscherkunde und Glazialgeologie 5(1): $1-59$

Kick W 1980 Material for a glacier inventory of the Indus drainage basin - the Nanga Parbat massif. International Association of Hydrological Sciences Publication 126 (Workshop at Riederalp 1978 - World Glacier Inventory): 105-109

Konecny G 1984 Die photogrammetrische Kameramission auf Spacelab-1. Zeitschrift für Vermessungswesen 109 $257-264$

Kravtsova V I 1982 Ispol'zovaniye kosmicheskikh snimkov v kartografirovanii gornogo oledeneniya [The use of space images in the mapping of mountain glaciers]. Materialy Glyatsiologicheskikh Issledovaniy. Khronika. Obsuzhdeniya 42: $18-22$

Mi Desheng, Luo Xiangrui 1983 Variations of the glaciers detected from the Landsat MSS images. Journal of Glaciology and Cryopedology 5(1): 71-78 
Mott P G 1950 Karakoram survey 1939: a new map. [With map.] Geographical Journal 116(1-3): 89-95

Rundquist D C, Collins S G, Barnes R B, Bussom D E, Samson S A, Peake J S 1980 The use of Landsat digital information for assessing glacier inventory parameters. International Association of Hydrological Sciences Publication 126 (Workshop at Riederalp 1978 - World Glacier Inventory): $321-331$

Scherler K E 1980 Report on world glacier inventory. Status Dec. 1980. Zürich, Temporary Technical Secretariat for the World Glacier Inventory

Schneider H-J, Baumert H 1968 Die Expeditionskarte Minapin: NW-Karakorum. [With map.] Zeitschrift für Vermessungswesen 93: 446-457

Schroder J F Jr 1980 Special problems of glacier inventory in Afghanistan. International Association of Hydrological Sciences Publication 126 (Workshop at Riederalp 1978 World Glacier Inventory): 149-154

Shi Yafeng, Zhang Xiangsong 1984 Some studies of the Batura glacier in the Karakoram mountains. In Miller $\mathrm{K}$ $\mathrm{J}$ (ed) The International Karakoram Project. Vol 1. Proceedings of the International Conference....Cambridge etc, Cambridge University Press: $51-63$

Spender M 1983 Shaksgam Expedition 1937. Himalayan Journal 10: 22-39

Workman F B, Workman W H 1908 Ice-bound heights of the Mustagh. London, Archibald Constable \& Co 